\title{
Concept Of God In Tennessee Williams And Rabindranath Tagore
}

\author{
Dr. Vidhu Gaur, \\ Assistant Professor, Alliance Business School, \\ Alliance University, Anekal Road, Bangalore (India)
}

\begin{abstract}
Compassion, love and emotions that are empathetic in nature form the crux of all work written by both Tennessee Williams as well as Rabindranath Tagore. A very deep understanding of the human nature coupled with an extraordinary theological bend is the characteristic of both their works. Half a century apart and born millions of miles distant to different religions, cultures as well as backgrounds, these two artistically gifted individuals have a twain that meets which tries to define the very nature of human existence the way it is. The variance in cultures or religion does not stop them from asking the same questions, looking for the answers to the riddle of human reality, the subtlety of the rhythms in appreciation of God and the deeper knowledge of the difference between good and evil. Just like Williams, Tagore never lost faith in God. He had conceived of a personal God, his life's God (Jiban-devata), in 'Gitanjali'. Then again, in the last years of his life, Tagore was to sing in praise of God in man, the Supreme Man.
\end{abstract}

Keywords: Anthropomorphic, Biraha, God of Love, God of Wrath, Nature's emissary, Nature's mockery, Oversoul

\section{INTRODUCTION}

"Hell is yourself and the only redemption is when a person puts himself aside to feel deeply for another person."'- 'Tennessee' Williams

Since birth, Thomas Lanier 'Tennessee' Williams had a special relationship with religion. His early life seemed to be framed by his relationship to his grandfather. Teachers called him a "preacher's kid." Not only was he saturated with the ceremonies and symbols of the Church of England, he was also convinced of the Christian vision of the world. He believed in God's existence, the afterlife, his particular role in human history, and his obligations to use his gifts for a preordained vocation. And this was not simply an intellectual construct. When he was seventeen, he had a mystical moment in the Cologne Cathedral: he said that he felt "the hand of our Lord Jesus" touch him with mercy and exorcise the phobia that was driving him "into madness" (Memoirs 1975, 21). Although he made fun of his innocent adolescent faith, he was always inclined toward some mysticism. He never lost his sense of transcendence, his belief in his own special calling. He said he knelt to pray before each new play opened. [1]

The problem of evil raises a difficult question for traditional religious believers in the West; if there is an all-powerful, all-good being, how can there be evil? The idea is that an all-powerful being would be able to abolish evil, and an all-good being would want to abolish it. Thus if there were such a being, there would be no evil. But there is evil, and so how can there be such a being? In this way, the problem of evil raises a serious challenge to belief in an all-powerful, all-good God.

A traditional western definition of evil emphasizes moral evil (wrongdoing) and natural evil (suffering). But Indian philosophy equates evil and imperfection. But imperfection, according to Tagore, is not just 'a negation of perfectness.' Instead it is 'completeness manifested in parts.' He says that 'what appears as imperfect is the manifestation of the perfect.' For Tagore the main question is not 'why is there evil?' since he thinks a created world has to be imperfect. For him the key question concerns whether evil is ultimate, final, or not. His answer is 'no'. [2]

Williams never shaped this set of beliefs into an explicit systematic statement. The ideas are apparent as the under girding of his plays. Once recognized, they help the reader/viewer to interpret the imagery, to understand the plot, to recognize the setting, to see the full meaning of the characters. This is particularly true of 'The Night of the Iguana', a play that pictures a cluster of pilgrims at the end of their road. Human life is often described as a path or a way. The seventeenth century novel John Bunyan's 'Pilgrim's Progress' left an indelible imprint on American literature, fixing firmly into the national psyche the concept of the journey of life. Even before that, it was already a solid part of Western thought, appearing frequently in Scripture, repeated in the classics, with their archetypal voyages to the unknown and the voyages back home, and in the medieval imagery of the religious pilgrimage. Thus, when Emily Dickinson speaks of setting out on a journey with Death, a gentleman who "kindly stopped" for her, we understand this in metaphysical terms. We also understand that 
Robert Frost was talking about more than just a fork in the road when he spoke of taking "the road less traveled." Then it is no surprise that someone as well versed in literature as 'Tennessee' Williams would use the imagery of the journey to explain the plight of his characters. [3]

\section{The Night of the Iguana}

The play 'The Night of the Iguana' is a remarkable elaboration of the earlier tale, with the central image of the iguana and elements of Williams' own life, particularly his long relationship with his grandfather. The "hero' of the play, the Reverend T. Lawrence Shannon, has been trying to act as the guide of tour groups, but he is unable to adhere to a schedule or keep his hands off the prettier and younger tourists. At this point, he is being fired by the tour company and abandoned by the furious ladies. These harpies are screaming at him because he has just seduced their favorite young girl and has also deviated from the published itinerary. They want their money back.

Shannon has brought his busload of screaming Texans to an old safe haven, a run-down hotel at the top of a hill in a rain forest adjacent to a saltwater beach near Acapulco. Maxine Faulk, the bawdy hotelkeeper of this dilapidated paradise, welcomes him. An old friend of Shannon's, accustomed to his regular breakdowns, she clearly wants him to settle in for the duration. Maxine has recently been widowed, is currently satisfying her appetites with nubile young natives, but eyes him as a prospective lover for the long term.

In this moment of his apparently inevitable capitulation to Maxine's generous but emasculating dotage, an alternative character trudges onto the scene: Hannah Jelkes, a sturdy New England spinster who has been touring the world with her 90-year-old grandfather. She has been earning her way as a quick-sketch artist and now, like Shannon, is at the end of her rope and also seeks to find a haven in this place. Maxine spots Hannah and her grandfather as penniless liabilities she is not willing to shoulder. She also calculates Hannah to be a potential competitor for Shannon's favors. It is no surprise that she tries to turn them away. Maxine has a soft spot -- though not a very large one -- that causes her to allow the odd couple to spend a single night in the hotel. This act of grace allows time for the play's action to unfold. The two women wage an undeclared war over Shannon.

The long evening moves from Shannon's confrontation with his female tormentors from the bus tour through his defeat and self-punishment to his confinement in a hammock and period of quiet communion with Hannah, who ministers to him and helps him back to the edge of sanity, He also comforts her, revealing vestiges of the old Shannon as a gentle pastor. She grows agitated at the sounds of the captive iguana scratching to escape. The natives have caught the ugly creature and plan to use it for a meal. At her request, Shannon "plays God" and cuts the rope holding the iguana, setting the creature free.

As the evening draws to a stormy conclusion, Nonno, Hannah's' grandfather, completes his final poem and then dies. Hannah prepares to leave the next morning, facing new customers, new friends, and new vistas. Although Shannon proposes to go with her, she tells him that they both know this is impossible. As the play ends, Shannon settles for Maxine's offer, agreeing tacitly with her that he could do worse.

For Hannah and Nonno, the pilgrimage has been less frenzied and more hopeful. Their discoveries along the way have been more benign, their love for one another has made for good fellowship and mutual support. Now, ready to part with her as he undertakes his solitary journey into death, Nonno seeks the path to the "cradle of life" -- the sea. He is selecting a natural and appropriate way for one in his nineties, not the rushed and violent choice that Shannon, in the middle of his journey of life, only halfheartedly contemplates. Nonno dies echoing some of the first words spoken by God and the last words by Christ: "It is good," and "It is finished." (Iguana 103) Although his granddaughter has to push his wheelchair up the narrow path to the top of the mountain, signaling his entrance into a second childhood, he is content with his life and with his death.

Hannah, finally free of her beloved encumbrance, must go on, following her own lonely path that will take her away from this "House of Dying" into new adventures. She and Shannon are both seekers, both Puritans working out their salvation in individual, existential ways. Hannah, the New England spinster, is a celibate with little real temptation for the flesh. In her journeys she had adopted the openness of Eastern mystics, who put tolerance before orthodoxy. She does not pass her judgment on Shannon's sins -- does not even label them "sins." She comments mildly on his unkindness to others and to himself. The violation of another's humanity is her ultimate evil, not a transgression of God's law. As a sketch artist, she observes and records without sitting on judgment.

Hannah's dispassionate observations are tempered with a generosity of spirit that allows her to give her last cigarette to Shannon and a piece of her underwear to a pitiful Australian salesman. She enthusiastically bears the burden of her grandfather's care to the very end of his extended life. She may be a "female standing up Buddha," but she is also a "Christian saint." At times, she acts as a Kabuki dancer performing ritual actions. At others, she acts the role of the Christian priest hearing confessions, giving ablution, and administering the sacraments. [4]

Shannon, the actual, ordained priest in the story, is at first eager to dress in his clerical costume, but then is even more eager to tear the splendid gold and amethyst cross from around his neck. The gift to Hannah 
of this ornamental cross at the end of the play, to fund her continued pilgrimage, is reciprocated by her promise to return it -- or the pawn ticket to redeem it at a later time. The very language of "redeeming" the cross, as was noted earlier, rather than being redeemed by the cross, signals the reversal of values in Shannon's life. He has betrayed his faith in his mad pilgrimage of the flesh, yet he cannot rid himself of the vestiges of that faith. He advertises himself as a minister of God leading tours to God's world, yet he takes his customers through the most depraved sights possible. He wins their respect for his theological training, forces them to recognize human depravity, and then seduces the prettiest, youngest, and most vulnerable of the flock. Filled with guilt and self-loathing, he subsequently punishes the partner of his lust. He remains a Puritan, ill at ease in the decadent tropics.

The key to the confusing blend of Freudian psychology, Eastern mysticism, and Christian tradition is found in the name of the tours that Shannon conducts -- Blake's Tours. William Blake, 'Tennessee' Williams' all-time favorite mystic poet, was an early English Romantic. He believed that the Christian life was almost the exact opposite of what people prescribed. For instance, he believed that God had created humans with good instincts that they should indulge in natural ways. God created and loved the tiger as well as the lamb, the passionate, dark mysteries of life as well as the simple, innocent beauties. Blake believed that the "dark satanic mills" of the industrial world were crippling and polluting God's good earth. He also believed that primly righteous people crippled and destroyed God's children.

The account of Shannon's childish practice of masturbation, which his mother interrupted and forbade, pronouncing that it made both her and God angry, had turned Shannon against all authority figures, which became symbols of sexual frustration. His image of God as a negative force, with the voice of thunder and lightning, grows out of a need to fight for his natural appetites. Blake, Williams appears to believe, would have approved of Shannon's judgments on the sick people and sick cities. He also would have sympathized with the tied-up iguana and applauded Shannon's freeing it as an act of grace.

The religious imagery that weaves through almost every speech in the play forces the audience to analyze the theological content and the author's implied message. Williams' religious message is invariably man-centered, with God a threatening background figure. His laws are perceived as arbitrary restrictions, not particularly helpful as guidelines for the good life. The plays almost always have a "fantastic" level that transcends reality, never settling for the flatly factual level of existence. Williams tends to focus on "big" questions -- self-discovery, death, beauty, truth, love, etc. For example, in 'The Night of the Iguana,' the concern is not whether Shannon can hold on to a job with Blake Tours, but whether he on the other hand can retain his dignity, discover his true path, and find meaning in his life. In spite of her poverty, Hannah has found an inner peace. She knows who she is, what she must do, and how she must live.

In the play 'The Night of the Iguana', we find a number of Williams' theological signatures: The setting indicates transcendence. In this case, the sea is the Over-soul waiting at the end of the path. The heat of the locale adds to Shannon's sense of decadence. The rainforest, teeming with life, symbolizes the earthly existence, fall of fertility and corruption. The hotel, our earthly dwelling, has its classic meeting place where the solitary lives mingle briefly. God strikes out in lightning and thunder, heals with rain. The wind is the Holy Spirit that brings healing and comfort.

Like most Americans, Williams was no philosopher or theologian. He made no effort to codify his evolving faith or match it against the ancient heresies it mirrored, yet his plays are often sermons aimed at the community he seeks to convert to his own personal vision of reality. He was like the roving evangelist who exploited the theatre as if it were a camp meeting, full of passion and conviction, not a carefully calibrated intellectual discourse.

\section{Tight Christian upbringing with non-conforming rationality}

While 'Tennessee' Williams, like much of the intellectual community of the $1960 \mathrm{~s}$, was attuned to Eastern mysticism in an effort to reach out to other religions with a fresh openness, he never quite relinquished his Episcopalian roots. This tension created both colorful imagery and cloudy theology.

He loved to focus on individual experience and feeling, a sense of well-being that might be enhanced by the use of alcohol or drugs. He adopted the imagery -- and perhaps the idea -- of the Over-soul. He was comforted by the Eastern absence of sexual regulation or Puritan morality, leaving the ethical decisions to be determined on a case-by-case basis -- a moral suasion called "situational ethics."

Williams wants us to see all of this: the beauty, the degradation; the courage, the fear; the rebellion and the surrender of the wayfaring pilgrim.

The elucidation of Christian symbolism is a commonplace of contemporary criticism. Naturally commentators have also scrutinized 'Tennessee' Williams' work and have managed to make almost each play yield its Christ figure. It has thus been repeatedly emphasized that a significant proportion of Williams' plays occur around or leads up to the liturgical feasts of Good Friday and Easter. If the events of the play is not near Easter, the plot reproduces more or less faithfully and noticeably some of the Easter week events. In all of these plays the playwright links his principal male character through his personal attribute or by his action to Christ, 
Val's second name "Xavier" in 'Battle of Angels' is meant to evoke the "Savior." Jim O'Connor in 'The Glass Menagerie' is associated with the unicorn, a traditional Christ symbol; Kilroy goes through the painful blocks of the 'Camino Real' that might represent the stations of Calvary; Sebastian in 'Suddenly Last Summer' is reported to have ascended a Golgotha-like mountain; Chance in 'Sweet Bird of Youth' expects his "resurrection" in Saint-Cloud on Easter Sunday; Shannon in The Night of the Iguana is seen bringing a heavy load up a mountain where he is about to be "crucified"; Christopher, in 'The Milktrain Doesn't Stop Here Anymore', whose name - most often shortened to "Chris" - already spells his relationship with Christ, similarly climbs Mrs. Goforth's mountain, in the heat of the afternoon, pursued by the clam out of the pack. Through the actions of these characters, elements of Christ's passion are reflected in the respective plays in which they appear. Sometimes the critics' attention is drawn to this pattern of symbolism rather clumsily as the "God-I, Lady-You" stammering of Val Xavier or in Flora Goforth's question to Christopher "Can you walk on water?" sometimes more subtly as when Jim O'Connor alters Laura "Life-Savers." [5]

One reason why Williams' characters frequently close their eyes to the needs of others is that they find some trait in those around them that disgusts them. In order to mean God to the other, one must be able to say, along with Hannah Jelkes in 'The Night of the Iguana' (1961), "Nothing human disgusts me unless it's unkind, violent." (Iguana, p.100) If one has such limitless compassion, he will never become so obsessed with the evil in himself or others that he denies the possibility of the good, nor will he be deliberately cruel to the other or sit in judgment upon him. So Hannah does not succumb to disgust or despair when she hears Shannon's story about an isolated incident of coprophagy, Just as earlier she maintained her equanimity when the underwear fetishist requested a piece of her clothing. Sympathetic to all human needs, she understood his request not as something "dirty" (Iguana, p.100) - as Shannon would name it — but rather as "a love experience," (Iguana, p.100) since it called for a response on her part to a "degree or depth of loneliness" (Iguana, p.100) she had never before encountered in one of God's creatures. For in Williams outcries for help require diverse responses, governed not by any preconceived notions of ethical behavior but instead by human need, our own or that of others. In Camino Real (1953), to leave his wife and sacrifice the warmth of "someone you're used to, and that you know loves you in order to protect his wife from the anguish of being tied to "a broken-down champ," with "the earth still turning and he obliged to turn with it, not out—of dark into light but out of light into dark. [6]

The motifs of allowing disgust for something human to prevent one's aiding another in time of need, as well as the possibility of bringing God to the other, are both evident in Williams' plays as early as A Streetcar Named Desire (1947). The event in the past most responsible for Blanche's present instability was her rejection of her young husband when she discovered his homosexuality. Her judgment, "You disgust me," (Streetcar, p.528) - albeit impulsive and hardly an act of deliberate cruelty - drove him to suicide. That she is still hounded by guilt over her failure is suggested musically by the strains of the Varsouviana which still haunt her. Blanche tried unsuccessfully to alleviate her guilt by a string of promiscuities, which she regarded as chances not to fail others as she had her husband. She enters the play in need of someone to love and reassure her, of someone to mean God to her by helping her rediscover belief in her own humanity, Blanche thinks she has found that person in Mitch, and "sometimes - there's God - so quickly!" (Streetcar, p.529) But just as she failed Allan in passing judgment upon him, so too, Mitch rejects Blanche when he learns of her debaucheries, destroying any hope, however slight, that she might regain her mental stability.

\section{Rabindranath Tagore's 'Nature's Revenge'}

In Indian philosophy, under the law of karma there is always a scope to strive for the better, because as Dr. S. Radhakrishnan very ably says, "Life is like the game of bridge. The cards in the game are given to us. We do not select them. They are traced to past karma but we are free to make any call we think fit and lead any suit. Only we are limited by the rules of the game. We are freer when we start the game than later on when the game has developed and our choices become restricted. But till the very end there is always a choice." [7] So the law of karma does not mar man's freedom of making choices. Notwithstanding the determinism that the law envisages, there is scope for making correct choices for the betterment of our future. And above all, the kind of determinism that the law of karma enforces is nothing other than our own past karmas. Therefore, in the Indian moral thought it is perfectly meaningful to say that a person is himself responsible for the good or bad consequences that he has to undergo because of his good or bad actions.

Rabindranath Tagore is the right representative of Indian philosophy:

Rabindranath's religion is identical with the ancient wisdom of the Upanishads, the Bhagavad-Gita and the theistic systems of a later day. [8]

There is an amazing and intimate parallelism between Rabindranath's mind and the mind that manifested itself in the Upanishads. This parallelism is amazing because it transcends the gap of at least three thousand years and yet remains very close and evident. [8]

Here we take the Indian drama 'Nature's Revenge' by Tagore to understand Indian philosophy to a greater depth particularly with reference to Tennessee William's views on God. The drama depicts only one main character - a proud and defiant hermit (sanyasi) who would no doubt have looked with contempt at the 
shy lonely young man who had been turning his adolescent sighs into still more adolescent poems. The poet and the hermit (sanyasi) were both absorbed in their painstakingly secluded selves, but there the similarity ends. The poet was sad and self-pitying in his loneliness; the hermit (sanyasi) is exultant and boastful in his complete selfsufficiency. The short drama begins with the expansive hermit (sanyasi) soliloquizing about his hard-won success in transcending the world - the world in so far it existed for him. Its sights and sounds do not reach him, its temptations do not touch him, its joys and sorrows do not affect him. Once, like everybody else, he too was a slave to nature, enchanted by desires, hopes and fears, running after earthly pleasures which if they were reached, vanished before they could be tasted and left only lasting bitterness, when the hermit (sanyasi) comes out of his dark cave, he finds Nature utterly insipid and dull, and sees, as if from a great height, insignificant men and women engage in the most trivial and silly pursuits. He expanded the verse of Buddha's declaration:

Subdued have I all, all-knowing am I now

Unattached to all things, and abandoning all

Finally freed on the destruction of all craving

Knowing it myself, whom else should I credit

There is no teacher of mine, nor is one like me

Truly entitled to honor am I, a teacher unexcelled

Alone am I Supreme Buddha, placid and tranquil

$\cdots$
Beating the drum of immortality in the world enveloped by darkness

In the hermit (sanyasi) as he is introduced to us in the opening scene of the drama, 'subdued have I all' is sounded with equal zest, but disgust with the normal course of life and hatred of 'the world enveloped by darkness' is even more pronounced. The next scene shows village folk engaged in all manner of tomfoolery and triviality. As the scene is preceded by two lines in which our hero says: "By now these people have become petty in my eyes,/ Let me cast a glance at the game of life they play", we get the impression that these scenes represent not an objective cross-section of village life but an aspect of that life as seen by the hermit (sanyasi) exulting in his self-accomplished alienation.

The drama is a play of changing attitudes, of how through various phases and reversals his initial contempt for everything is transformed into love which knows no bounds, and finally into something like the Shakespearean realization - 'Ripeness is all." The instrument of change is a little orphaned, outcast girl, seeking shelter from door to door and passerby to passerby. But everyone turns her out or turns away from her. In this helpless condition she encounters the hermit (sanyasi) and runs to him for succor. The hermit (sanyasi) takes kindly to her. The girl responds by calling him father and snuggling close to him. A chord is struck and there is an affectionate response. But the hermit (sanyasi) is annoyed with himself: had he not conquered and risen above such frailties? He turns away, but the girl follows him. Thus begins that inner struggle, the oscillation between affectionate warmth and cold detachment, which gives the drama the aesthetic value it possesses.

What is remarkable is that in learning to love the girl, the hermit (sanyasi) is beginning to find interest and joy in the world. While struggling to recover his detachment, he says that Nature is mocking at him through the little girl's enchanting laughter. But soon he begins to regard her as an epitome of the whole world; from Nature's mockery she becomes Nature's emissary.

There is an intermediate stage in the transformation of the hermit's (sanyasi) mind in which he has ceased to hate the world but has not yet learnt to love it. He makes a noteworthy soliloquy.

With what mighty rhythm this cosmos dances

Light and shade, life and death

Sun, moon and stars

Are but footsteps of that dance

I am not one of them [10]

The hermit (sanyasi) passes beyond this state only to return to it after the most tragic moment of his life. This state may be regarded as the poetic state par excellence - contemplating the course of the world with calm detachment and from an aesthetic distance. He does not remain long at the intermediate level. Several times he runs away from the outcast girl leaving her in tears. His final departure and arrival make the most poignant scenes of the drama. Finally the hermit (sanyasi) develops the tenderest feelings for the girl, and through love of her he learns to see worth everywhere - in the course of Nature and in the current of life. This anguishes him and makes him angry with the girl: for isn't she the cause of his defeat, the cause of his fall from the Himalayan peaks he had climbed to conquer all that was human in him and become self-sufficient like God? He decides to recover his past glory by returning to his unperturbed seclusion in the cave once for all.

But this is not possible now: however far he may go into the forest, he can no longer be alone. The little girl's face and voice and laughter haunt him; she fills a void in his life that was craving to be filled: so does the world which she had brought to him along with herself. The world is different now that he has begun to look at it with the affection which he had developed for the girl. He discovers a new truth, a great truth. The 
truth is that love not only changes one's life, it changes the whole world. What is commonplace and dull to the indifferent eye becomes charged with endless mystery and beauty in the eyes of love.

God is conspicuously absent from this drama which otherwise strikes us as religious in its import. God has been sought by saints and mystics in and through worldly aspects, as well as apart from the worldly elements, away from these factors, in inaccessible forests and caves. There have been world-loving mystics as well as world-hating mystics. But they all loved God. The hermit (sanyasi) of Nature's Revenge was not a mystic in the accepted scene of the word, for he loved nothing so long as the little girl had not come across his path. He lived in a dark cave because he hated both man and Nature. He contemplated but did not love the abstract infinite. The girl awakens love in his breast which overflows and spreads over all mankind and all Nature. But he returns to the village to look for the girl, she is nowhere to be seen. In the English version of the play he hears her death from a passing woman. Naturally he finds that unbelievable. When the woman repeats her information, he firmly asserts: "She can never be dead." And that is the last line of the English version of the drama.

\section{Meeting of the Chord}

Thus we see that Indian philosophy or precisely Rabindranath Tagore's philosophy goes with Williams' views of replacing God with love and compassion. Blanche and Brick, lacking the wisdom of a Hannah or a Maggie, each assumed the role of wrathful God and passed judgment upon another person; now both of them need some assurance that a loving God exists. Since Williams conceives of God as anthropomorphic, made in man's own image and likeness, the assurance that Blanche and Brick crave can come only from another person who reaches out to them with love.

There are some male characters in Williams who become so obsessed with the evil in themselves and in those around them that they transfer this evil to God, creating a God devoid of any goodness or love. The characters deny themselves the possibility of redemption because of their own distorted vision of God; Lawrence Shannon in The Night of the Iguana, is saved because Hannah helps him perceive just how distorted his vision of God really is.

Shannon's crisis in faith springs from his conception of God as a vindictive God who denies man his pleasure, for Shannon has always felt a compulsion to sin-especially to sins of the flesh, like Chicken in Earth-followed immediately by guilt and remorse and the need to be punished. Shannon is too preoccupied with his evil and guilt, and thus too obsessed with a sense of his failure in life. He does not realize that to be human is to be sinful, but not so flawed as to despair, but fortunately, Shannon has just enough emotional reserve left to muster some sympathy for someone outside of himself. Hannah calls him "as man of God, on vacation," (Iguana, p.67) and recognizes, as the stage direction suggests, that the infirm grandfather Nonno, "ninety-seven years young" (Iguana, p.67) and "the oldest living and practicing poet," "touches something in [Shannon] outside of his concern with himself." (Iguana, p.68) Hannah helps Shannon to gain a renewed belief in his own goodness and kindness by prompting him to perform the "little act of grace" of setting the iguana free; as Shannon says, "God won't do it and we are going to play God here." (Iguana, p.104) Like Coleridge's 'Ancient Mariner' who "blessed [the water snakes] unaware" and then saw the albatross fall from off his neck, Shannon rips his own albatross - the gold cross which symbolizes a perverted system of religion by which he feels condemned rather than re deemed-from around his neck. Only after Shannon finishes his last and "loveliest poem," whose subject is that man cannot live in a perfect, uncorrupted world, but must have the courage to endure in the face of evil and suffering, without ignoring the good or despairing over the human condition. Since such courage can come only by recognizing the "broken gates between people so they can reach each other" and by accepting the interdependence of all creatures, Williams gives to Shannon a name containing the alphabet letters needed to spell out "Nonno" and "Hannah". [11]

In an early one-act; "The Lady of Larkspur Lotion" (1945), one of Williams' characters asks; "Is there no mercy left in the world anymore? / What has become of passion and understanding? / Where have they all gone to? Where's God? / where's Christ?" Williams' own answer given throughout his major plays is simple without being simplistic. It is given in the form of a challenge which must not frighten; we must be like God to the other, and the other must be like God to us. [12]

Of things he was subjected to, because of what he has experienced in a familiar way, and because of what he knows, Williams presents to date a highly ambivalent attitude toward God. He does not know as yet which fork in the sentence will end in an accurate completion. Inductively seining his plays' functional religious trappings and overt theological statements against the interpretative biography "written" by his mother, one can construct--like Cocteau on "Saint" Genet--the ambivalent theological stance of Tennessee Williams. It is in this "knightly quest" that Williams promotes the religious act of his theatre; it is the lack of "time for contemplation," the lack of the necessary "introversion" for which Williams censures America in his novella, the off-stage comment of The Knightly Quest. 
Unbelief for Williams is impossibility; for unbelief is inorganic in the sense that it is an interruption in the development of the whole, created personality. Despite the Freudian fingers popularly pointed at Williams, the playwright's principle of belief is totally un-Freudian. (Freud, an unbeliever himself, said that 'experience of God is reducible and that unbelief represents a higher degree of development, while belief represents retrogression to a lower degree of the sense of realism.' [13] Williams nowhere doubts God as a primary cause. In his characters' heavily felt sense of creature hood he elaborates his full belief that God is the whole of everything, is the cause of everything. It is, however, the nature of this Prime Causality that greatly disturbs the Williams world.

Williams and his characters see God in two ways; Shannon's sentence can be completed by one or the other selections in Williams' multiple choice. God is perceived either as an Old Testament God of Wrath ruling over a semi-Calvinistic cycle of guilt-submission-atonement-uncertainty or a New Testament God of Love offering a cycle of need-submission-communication-salvation. In either case, however, surrender of the creature is required, and it is here that Williams' difficulty begins; for the idea of God in man is not a flash occurrence; it is the result of organic growth. From identification with parents, siblings, and others in the domestic environment, the personality develops an ego-ideal which is free of the short-comings of the real ego. A tension develops between egos. 'Consciously or unconsciously, the proper ego makes continual comparison with the ideal ego. Conscience, feeling of guilt, self-criticism are the usual expressions of this relationship.' [14] Beyond this ego and super-ego development lies the awakening of the libido on the sensory levels of oral-eroticism, anal-sadistic phase, and the genital stage. The Oedipus complex which arises during the genital stage as a boy fixates on the mother with a concomitant repulsion for the father becomes latent after the genital stage until puberty when it is revived and normally solved.

God exists for Williams as factually as does his father; but the way to approach that fact is a psychic problem. Not to know whether God is an avenger (this eschatology leads to the basic existential desperation in all Williams' plays) or whether he is a lover (as Williams hopes) loved in what seems more than a make-shift way in other people, leads Alexandra to pry in the last act of Sweet Bird: 'Someday the mystery god may step down from behind his clock like an actor divesting himself of make-up and costume.'

Williams' God is, in short, the father of the fragile Menagerie, the father who fell in love with long distance. His existence is known, but he sends no word, no address; he makes no claim to the worn-out records he left behind. The family he abandoned, the brotherhood of men, must cling together--the only sure hope--to belie the statement of Sweet Bird's Heckler who says: 'I believe that the silence of God, the absolute speechlessness of Him is a long, long and awful thing that the whole world is lost because of.' (Sweet Bird, p. 433.)

Tagore tries to show how Hinduism can make sense of evil. He maintains that evil is not absolute but leads to other goods, especially the good of our recognizing the identity with God. Tagore points out that a river has banks, but they are not the 'final facts' about it. They help serve the purpose of moving the water on. The world too has its boundaries, but its purpose is not found in them but in its movement towards perfection. According to him, facing our limitation in knowledge, power, and will can also help us realize our true selves. Realizing our weaknesses may make us miserable, but this realization also points to an ideal of perfection. According to this ideal, the infinite is in us, i.e., 'man has oneness with God.' Thus our true self is not an individual self but a universal self. We are part of God.

If we are part of God, then that raises an important question: where is the evil coming from? Tagore says that much evil is coming from our lack of understanding about our true natures. When we fail to merge the finite self into the infinite self, we are less likely to act from disinterested goodness. Not having the right fit between the individual self and the universal self causes much suffering. He says, "It is our life of self that causes conflicts and complications everywhere, upsets the normal balance of society and gives rise to miseries of all kinds." Our lack of understanding then makes us the source of much evil.

Finally, Tagore says, "As it is, man does not really believe in evil." He maintains that those who claim that existence is an absolute evil "cannot be taken seriously; they are merely posing." Tagore maintains that evil is not absolute, since it can lead to the important good. As a discordant part of the world, evil can make the whole world better. It can help us develop our characters and realize our identity with God. [15]

According to Thomas P. Adler, Tennessee Williams conceives of God "as anthropomorphic, made in man's own image and likeness." Williams himself confirmed this view in his Memoirs, when he admitted to a friend that he believed in angels more than he did in God: "and the reason was that I had never known God...but that I had known several angels in my life...I mean human angels." Perhaps nowhere in Williams' drama is this anthropomorphic vision more apparent than in the portraits of his unseen characters. Whether they are figures of cruelty or of tenderness and love, Williams' unseen characters are invariably presented as omnipresent. Even minor versions of this character type, such as the homosexual lovers Jack Straw and Peter Ochello in 'Cat on a Hot Tim Roof', are pictured as possessing supernatural powers, having "gently and poetically haunted" the scene of the play. [16] 
Worshipped like deities, Williams' unseen characters initially bring happiness and love into the lives of his protagonists - the "love which is glory," as Serafina Della Rose calls it. But when that transcendent love is lost, as it inevitably is, the same unseen characters produce pain and confusion, driving Williams' protagonists to irrational behavior and even to the brink of insanity. As the doctor in 'The Rose Tattoo' explains to Father DeLeo, people "find God in each other. And when they lose each other, they lose God and they're lost." It is this tragic experience of loss - comparable to the loss of one's religious faith — which Williams often movingly portrays. [17]

Despite the diversity of his dramas, Tennessee Williams essentially tells the same story over and over again. He records the yearnings of the loveless, the cries of the desperately lonely. In a number of plays William's protagonists long for the affection of someone who is nearby, yet unattainable. But in other dramas Williams' characters yearn for a love that is irrevocably lost, a love that can be called to life again only by means of memory and imagination. Through the device of the unseen character, Williams intensifies the spirit of loneliness and longing which pervades many of his plays; for by making the loved one unseen, he suggests that ideal love quickly vanishes, that it belongs solely to a world of illusion. At the same time, however, Williams testifies to the power of the illusion itself- to the preciousness of a love which binds two human beings together and which grants them at least a fleeting image of God.

God is also one of the unseen characters in William's plays. God brings happiness and love and His absence proves psychologically devastating for William's onstage characters. Tagore prepared himself to do away with all religions. The Upanishads taught him to be free of all bondages, for he found nobility in the search for truth by science. Tagore maintained that the Universe can have no existence that is independent of Man, because the scientific conception of it must be that of the scientific man

With regards to Tagore's search for truth by science there is a very interesting anecdote about a conversation that Tagore had with Einstein in 1930 at the Professor's residence in Kaputh, Berlin, Germany on propositions of truth, reality, beauty and universal being:
Einstein:
Tagore:
Truth, then, or Beauty, is not independent of Man?
Einstein:
No.
Tagore:
If there were no human being any more, the Apollo of Belvedere would no
Einstein: longer be beautiful?
Tagore:
No.
Einstein:
I agree to this conception of Beauty, but not with regard to truth.
Why not? Truth is realized through man.
I cannot prove that my conception is right, but that is my religion. [18]

Tagore used the simile of scientific matter being composed of protons and electrons with gap between them. Matter seems to have a solid state. Similarly, humanity is composed of individuals, yet they have their interconnection of human relationship, which gives living solidarity to man's world. The universe is linked up with us in a similar manner, it is a human universe.

To Tagore knowledge, love, and work, one without the other two, were ineffective. He sang in praise of a nameless God:

\section{Song \# 1}

Song \# 5

O now beneath your feet's dust let my head kneel on the ground

O you who know heart's deeper power make my heart flower

Song \# 4

Song \# 58

In danger save me - such a prayer

is not of my heart's choosing

but that in danger I stay free from fear

When life is all wrung out and dry

in an impulse of kindness, come [19]

Tagore's conception of God shows enormous complexities. He followed the teachings of the Upanishads and yet did not believe in the usefulness of asceticism and renunciation. According to him, to love God one has to work for the betterment of mankind and creation as a whole.

Song \# 119 states: 
You seek salvation? Where will you look?

Where is salvation found?

The Lord, self-linked with all, must be

to the mass of people bound [20]

Tagore had internationalized an external God, and his prayers were directed at God residing in him. He was of the view that when a man realized his true self he becomes a Supreme or Universal man. People of the world irrespective of their caste, creed, race, or religion can become one with God within, and can make true pilgrimage to the external world.

In song \# 106 of 'Gitanjali’ he sang:

I spread my arms here - I revere and worship God-in-man:

his praise repeat, to joy's fierce beat, with all the heart I can.

Even with such oneness of man and God, their duality was lost altogether, as expressed in Song \# 107:

Pride is denied your to-and-fro in ragged clothes of cheapest cost, among the least, among the low, among the lost.

And in song \# 119 we find these lines,

He has gone to break the ground that the farmer breaks -

or breaking stones with the one who year through, a new road makes. [21]

Whenever Tagore suffered from pangs of separation from God, he was soon reassured that God never actually did leave him.

Song \# 49 states:

She is present day and night

in the house we share.

In the morning with her laughter

light pours on the air

Song \# 52 has the line:

With your presence you immerse the sky and earth and universe.

From my heart, O may this word

be said and granted the saying of. [22]

Tagore realized that God was keener than he to establish a relationship so that His joy (ananda) could be fulfilled.

Song \# 130 says:

In me your own sweet-life-game has its play, and that is why on Earth I have my day.

Such thoughts of union with God intensified his desire to see Him in his real self. But his wish was not granted. He felt sad - the sadness of separation (biraha) had become the central theme of many songs of 'Gitanjali'. Strangely enough such sadness or separation (biraha) transcended to become a source of true happiness or joy (ananda). There, however, were moments when such separation (biraha) became unbearable. In that vein, Song \# 57 sings: 
Take me, Lord, take hold of me:

do not go back this time but stay

and keep me in captivity.

The old time of your being away

I do not long for. Let that day

depart all dustily. [24]

Tagore realized that the pain of separation was caused by his lack of understanding of the game God played. He was unsure about the uninterrupted presence of God within him. But once doubts were lifted, he was happy to find that God was always there and ready to play with him.

The glorious beauty of nature (prakriti) appeared as an expression of God's love, a beauty of nature that could not be experienced by the application of physical laws.

Song \# 30 sings:

Dear one, this is your love

O my heart - thief

A golden-hued dancing light

over a leaf;

a honey-cloud upon the sky

floating thoroughly lazily by; [25]

Nature provided a vast field for playing games with his Creator. Like the experience of the sages (rishis) of the Upanishads, he found the existence of a blissful joy everywhere. Such a notion of union with God elevated his mind to a height when poverty, meanness, insignificance of mundane chores, sadness, happiness, and pride of achievements were of no significance to him. To consider them important was false knowledge (avidya). He felt that true happiness would be brought by shedding selfish desires and by doing selfless works for others. At other times he convinced himself that all opposites like good and bad, happiness and sadness, day and night, life and death, were nothing but components of blissful joy (ananda).

Song \# 146 sings:

By your nectar's sending

in deathless streams descending, death's pierced - and all's restored.

Where want had been unending.

In fortune's sad reversal

true sense makes an arrival:

in conflict's din and quarrel

is your far-reaching word [26]

\section{Conclusion}

Just like Williams, Tagore never lost faith in God. He had conceived of a personal God, his life's God (Jiban-devata), in 'Gitanjali'. Then again, in the last years of his life, Tagore was to sing in praise of God in man, the Supreme Man.

Do we reach any defined form of answer to any of the questions after reading and understanding all the drama, poetry and any form of written art that these two artists created? No. They do not answer the questions, they try to do so and they kept it open for us to perceive, believe and further ask. For is it not that, which makes an artist - Someone who tries to answer a question and then forms his own principle which does not adhere but churns further queries that makes creativity to open into spaces of additional advancements.

\section{References}

[1.] Nancy M. Tischler, Alternate critical perspective: religious/theological interpretation, student companion to Tennessee Williams (London: Greenwood Press Westport, 2000) 134

[2.] Gregory P. Rich, Rabindranath Tagore and the problem of evil, in Roma Dutta and Clinton Seely (Ed.), Celebrating Tagore

(New Delhi: Allied Publishers Private Limited, 2009) 194.

[3.] Tischler, Student Companion, 136.

[4.] Tischler, Student Companion, 137.

[5.] Gilbert Debusscher, Tennessee Williams: lives of the saints: a playwright's obliquity, in Stephen S. Stanton (Ed.), Tennessee Williams: a collection of critical essays (New Jersey: Prentice-Hall, 1977) 149. 
[6.] Thomas P. Adler, The search for god in the plays of Tennessee Williams, in Stephen S. Stanton (Ed.), Tennessee Williams: a collection of critical essays (New Jersey: Prentice-Hall, 1977) 140.

[7.] Kedar N. Tiwari, Basic presuppositions of morality: classical Indian ethical thought (Delhi: Motilal Banarsidass Publishers, 1998) 141.

[8.] Abu S. Ayyub, Nature's revenge and sacrifice: Tagore's quest (Calcutta: Papyrus, 1980) 1.

[9.] Ayyub, Tagore's Quest, 14.

[10.] Ayyub, Tagore's Quest, 15.

[11.] Adler, Critical Essays, 147

[12.] Adler, Critical Essays, 148.

[13.] H.C. Rümke, The psychology of unbelief: character and temperament in relation to unbelief (New York: Sheed and Ward, 1962) 20.

[14.] Rumke, Psychology of Unbelief, 52.

[15.] Rich, Celebrating Tagore, 192.

[16.] Adler, Critical Essays, 139.

[17.] Susan Koprince, Tennessee Williams's unseen characters, in Harold Bloom (Ed.), Tennessee Williams's: cat on a hot tin roof (New Delhi: Viva Books P. Ltd., 2007) 81.

[18.] Ayyub, Tagore's Quest, vi.

[19.] Samir K. Gupta, Spirituality in Tagore's gitanjali, in Roma Dutta • Clinton Seely (Ed.), Celebrating Tagore (New Delhi: Allied Publishers Private Limited, 2009), 182.

[20.] Gupta, Celebrating Tagore, 183.

[21.] Gupta, Celebrating Tagore, 185.

[22.] Gupta, Celebrating Tagore, 187.

[23.] Gupta, Celebrating Tagore, 188.

[24.] Gupta, Celebrating Tagore, 188.

[25.] Gupta, Celebrating Tagore, 189.

[26.] Gupta, Celebrating Tagore, 191.

[27.] Tennessee Williams, A streetcar named desire: collected stories (New York: New directions, 1992) 469-564.

[28.] Tennessee Williams, Cat on a hot tin roof: collected stories (New York: New directions, 1992) 875-1005.

[29.] Tennessee Williams, The night of the iguana: collected stories (New York: New directions, 1992) 55-104.

[30.] Tennessee Williams, The glass menagerie, in Dr. Egbert S. Oliver (Ed.), American literature 1890-1965 an anthology (New Delhi: Eurasia Publishing House (P) Ltd., 1970) 237-305. 